\title{
Four Species of the Genus Atylus from Korea (Crustacea: Amphipoda: Dexaminidae)
}

\author{
Young-Hyo Kim and Kyung-Sook Lee* \\ Department of Life Science, College of Advanced Sciences, Dankook University, \\ Cheonan, Chung-nam 330-714, Korea
}

\begin{abstract}
Four species of the genus Atylus belonging to the family Dexaminidae are reported from the eastern and southern coasts of Korea. Three of these species are redescribed as new records of this country: Atylus (Atylus) ekmani (Gurjanova), A. (A.) matsukawaensis Hirayama and Takeuchi and A. (Kamehatylus) japonicus Nagata.
\end{abstract}

Key words: Atylus, Dexaminidae, Amphipoda, new records, Korea

\section{INTRODUCTION}

Atylus Leach, 1815 is one of large ones among 19 genera known in the family Dexaminidae. It consists of two subgenera, Atylus and Kamehatylus (Barnard, 1970). The subgenus Kamehatylus is characterized by the coalescence of urosomites 1-3 and absence of mandibular palp. There are only two species known in this subgenus: Atylus (Kamehatylus) nani Barnard, 1970 from Hawaiian Islands and Atylus (Kamehatylus) processicer Sivaprakasam, 1970 from India. Thirty-seven species have been reported in Atylus from the world, distributed in the above two subgenus (Ren, 2006). In Korea, four species of two genera, Atylus and Paradexamine, of the family Dexaminidae are previously recorded (Kim et al., 1992, 2006; Kim and Lee, 2008), including an atylid amphipod, A. collingi (Gurjanova, 1938). Here we add three species, A. (A.) ekmani (Gurjanova, 1938), A. (A.) matsukawaensis Hirayama and Takeuchi, 1993 and A. (K.) japonicus Nagata, 1961 into Korean atylid gammaridean fauna.

\section{SYSTEMATIC ACCOUNTS}

Order Amphipoda Latreille, 1816

Suborder Gammaridea Latreille, 1803

Family Dexaminidae Leach, 1814

${ }^{1 *}$ Genus Atylus Leach, 1815

Atylus (Atylus) collingi (Gurjanova, 1938)

Nototropis collingi Gurjanova, 1938, p. 328, fig. 38; 1951, p. 688, fig. 476; Tzvetkova, 1968, p. 172.

Atylus collingi: Barnard, 1958, p. 30; Kim et al., 1992, p.

\footnotetext{
*To whom correspondence should be addressed

Tel: 82-41-550-3449, Fax: 82-41-550-3440

E-mail: kslee@dankook.ac.kr
}

102, figs. 1, 2 .

Atylus (Atylus) collingi: Barnard and Karaman, 1991, p. 263.

Material examined. 1 우, Geojin, Goseong-gun, (38 $26^{\prime} 38^{\prime \prime}$

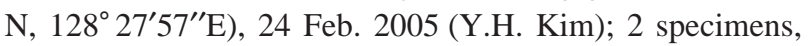
Gajin, Goseong-gun, (38 $\left.22^{\prime} 02^{\prime \prime} \mathrm{N}, 128^{\circ} 30^{\prime} 45^{\prime \prime} \mathrm{E}\right), 25$ Feb. 2005 (Y.H. Kim); 1 우, Bongpo, Goseong-gun, $\left(38^{\circ} 15^{\prime} 07^{\prime \prime} \mathrm{N}\right.$, $\left.128^{\circ} 34^{\prime} 02^{\prime \prime} \mathrm{E}\right), 23$ Feb. 2007 (Y.H. Kim); 7 specimens, Gajin, Goseong-gun, $\left(38^{\circ} 22^{\prime} 02^{\prime \prime} \mathrm{N}, 128^{\circ} 30^{\prime} 45^{\prime \prime} \mathrm{E}\right), 23$ Feb. 2007 (Y.H. Kim); 1 specimen, Gisamun, Yangyang-gun, $\left(38^{\circ} 00^{\prime}\right.$ $38^{\prime \prime}$ N, $128^{\circ} 43^{\prime} 46^{\prime \prime}$ E), 19 Dec. 2007 (Y.H. Kim).

Previous record. Geojin (Kim et al., 1992).

Distribution. Korea (east coast) and Russia.

2*Atylus (Atylus) ekmani (Gurjanova, 1938) (Figs. 1-3)

Nototropis ekmani Gurjanova, 1938, p. 323, fig. 35; 1951, p. 685, fig. 473; Bulycheva, 1957, p. 103; Tzvetkova, 1968, p. 172.

Atylus ekmani: Barnard, 1958, p. 30; Okado, 1993, p. 6, figs. 1-4.

Atylus (Atylus) ekmani: Barnard and Karaman, 1991, p. 264.

Material examined. 22 우 우, Geojin, Goseong-gun, $\left(38^{\circ} 26^{\prime}\right.$ $\left.38^{\prime \prime} \mathrm{N}, 128^{\circ} 27^{\prime} 57^{\prime \prime} \mathrm{E}\right), 24$ Feb. 2005 (Y.H. Kim); 1 우, Gajin, Goseong-gun, $\left(38^{\circ} 22^{\prime} 02^{\prime \prime} \mathrm{N}, 128^{\circ} 30^{\prime} 45^{\prime \prime} \mathrm{E}\right), 14$ Mar. 2006 (Y.H. Kim); 1 specimen, Bongpo, Goseong-gun, (38 $15^{\prime}$ $07^{\prime \prime} \mathrm{N}, 128^{\circ} 34^{\prime} 02^{\prime \prime} \mathrm{E}$ ), 23 Feb. 2007 (Y.H. Kim); 5 specimens, Gajin, Goseong-gun, (38 $\left.22^{\prime} 02^{\prime \prime} \mathrm{N}, 128^{\circ} 30^{\prime} 45^{\prime \prime} \mathrm{E}\right), 23$ Feb. 2007 (Y.H. Kim).

Description. Adult female: Body (Fig. 1A) about $18.7 \mathrm{~mm}$ long and strongly compressed laterally. Rostrum elongated, reaching $2 / 3$ part of article 1 of antenna 1 . Dorsal margins carinated, pereonite 6 to pleonite 2 with posterodorsal tooth, 


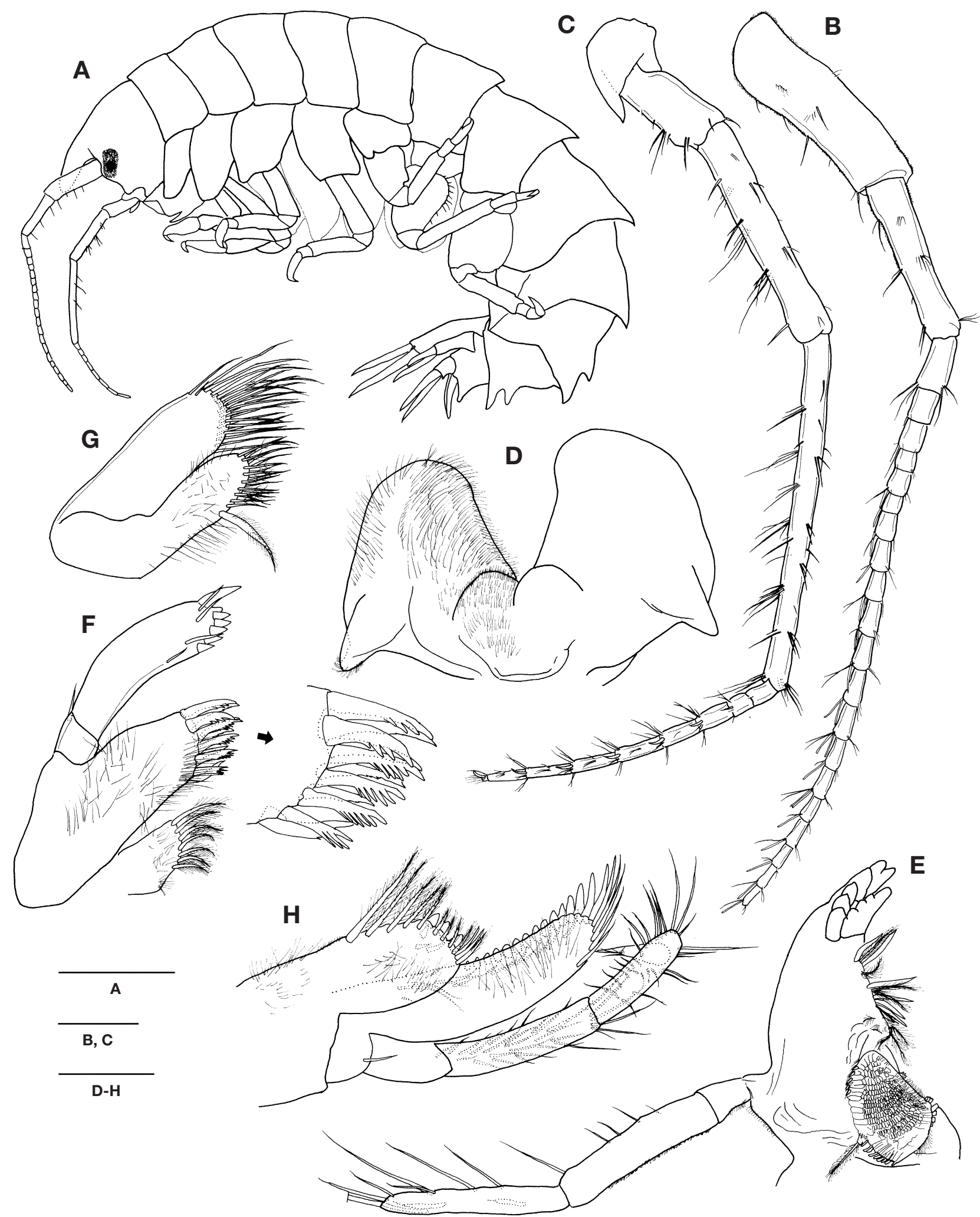

Fig. 1. Atylus (Atylus) ekmani (Gurjanova), female, $18.7 \mathrm{~mm}$ : A, habitus, lateral; $B$, antenna 1 ; C, antenna 2; D, lower lip; $\mathrm{E}$, mandible; $F$, maxilla 1 ; $G$, maxilla 2 ; $H$, maxilliped. Scale bars $=2.0 \mathrm{~mm}(A), 0.4 \mathrm{~mm}(B, C), 0.2 \mathrm{~mm}(D-H)$. 
pleonite 3 and urosomite 1 with 2 posterodorsal teeth, urosomites 2 and 3 coalesced with posterodorsal tooth.

Antenna 1 (Fig. 1B). Ratio of length of peduncular articles $1-3=1.00: 0.77: 0.26$; flagellum 19-segmented, 1.26 times as long as peduncular articles, provided with 1 or 2 aesthetascs on segments.

Antenna 2 (Fig. 1C). As long as antenna 1; peduncular articles 1-2 short, peduncular article 30.66 times as long as peduncular article 4, peduncular article 5 elongate; flagellum 9-segmented including short distal segment, provided with 1 spine and several setae at segments.

Lower lip (Fig. 1D). Outer and inner lobes with densely pubescent; inner lobe small, outer lobe with mandibular process.

Left mandible (Fig. 1E). Incisor produced forward, with 6 blunt teeth, lacinia mobilis well developed, with 5 teeth; molar process well developed, truncate, with a pappose setae; row of several stout and plumose slender setae placed between lacinia mobilis and molar process; palp well developed, triarticulate, rather slender, proximal article short, distal article slightly longer than article 2 .

Maxilla 1 (Fig. 1F). Inner plate apically bearing 6-7 pinnate setae; outer plate with 11 sclerotized simple or irregularly serrate stout spines; palp biarticulate, proximal article short, distal article with 4 simple setae and 6-7 conical spines.

Maxilla 2 (Fig. 1G). Inner plate smaller than outer plate, with stout pinnate seta laterally; apical and subapical margins of both plates with closely simple or pinnate setae.

Maxilliped (Fig. 1H). Inner plate subrectangular, with row of 5 pinnate setae laterally, 3 conical teeth and 7 simple or pinnate setae apically; outer plate extending beyond article 2 of palp, inner margin armed with row of conical teeth and exterolateral simple setae; palp 4-articulate, rather slender, article 2 elongate, longer than the other articles, articles 2-3 bearing many simple setae exteriorly.

Gnathopod 1 (Fig. 2A). Coxa 1 gradually narrowing distally, posterior margin bearing row of setae; basis rectangular, 1.64 times as long as merus and carpus combined, anterior margin with weakly short setules, posterior margin with row of irregularly long simple setae and distal half of posterior margin with short simple setae; posterior margins on merus to propodus with stiff setal clusters; carpus subtriangular, gradually becoming wider, 1.10 times as long as merus; propodus 1.18 times as long as carpus, inner face with five rows of simple or serrate spines obliquely, palm with row of long to short feeble setae, palmar corner bearing two groups of spines and setae; dactylus falcate, 0.50 times as long as propodus.

Gnathopod 2 (Fig. 2B). Similar to gnathopod 1, but somewhat longer, especially carpus and propodus; coxa 2 subtriangular, gradually attenuated ventrally, proximal half of posterior margin with simple long setae; basis 1.51 times as long as merus and carpus combined, posterodistal margin bearing several clusters of simple or serrate setae; carpus 1.06 times as long as propodus.

Pereopod 3 (Fig. 2C). Coxa 3 wider than coxa 2, ventrally portion pointed, with simple seta; basis slightly longer than merus, with 2 anterodistal spines; propodus 1.67 times as long as carpus.

Pereopod 4 (Fig. 2D). Similar to pereopod 3, except coxa 4 quadrilateral.

Pereopod 5 (Fig. 2E). Smaller and shorter than pereopods 6-7; coxa 5 anteriorly rounded, bilobate, anterior lobe protruding downward; basis subrectangular, bearing anteriorly long setae, posteriorly row of short setae, 0.93 times as long as merus; carpus 0.76 times as long as propodus.

Pereopod 6 (Fig. 3A). Similar to pereopod 5, but longer and more spiniferous; coxa 6 with straight anterior margin, basis lacking posterodistal process; merus elongate, 3.17 times as long as carpus; carpus 0.84 times as long as propodus.

Pereopod 7 (Fig. 3B). Coxa 7 subrectangular, anterior margin with long simple setae; basis subovate, about 0.8 times as wide as long, with broad posterior lobe, proximal $1 / 3$ of anterior margin with simple long setae; merus more than twice length of carpus, less than twice length of propodus.

Uropod 1 (Fig. 3C). Peduncle 1.22 times as long as inner ramus, with three rows of spines and 4 interior setae; outer ramus 0.85 times as long as inner ramus.

Uropod 2 (Fig. 3D). Peduncle subequal in length to inner ramus, 1.50 times as long as outer ramus.

Uropod 3 (Fig. 3E). Peduncle short, bearing apicolateral spine, about 0.5 times as long as outer ramus; inner ramus slightly longer than outer ramus.

Telson (Fig. 3F). Comparatively longish, slightly tapering distally, cleft along approximately about $2 / 3$ its length and terminating in an acute tip on each lobe, each lobe with two rows of feeble setae marginally, one pair of supple setae medially, apices with stout robust spine and 2-3 feeble setae, respectively.

Remarks. Atylus (Atylus) ekmani (Gurjanova, 1938) is characterized by having the 1) strongly compressed body form 2) pointed 1-3 coxal plates ventrally 3 ) pleonite 3 , urosomite 1 armed with 2 dorsal teeth and last urosomite with one dorsal tooth, respectively. Our specimens were identified as $A$. (Atylus) ekmani in having these diagnostic characters. This species distributed in Pacific boreal region such as Okhotsk Sea, Bering Sea (Gurjanova, 1951; Bulycheva, 1957; Tzvetkova, 1968), Sakhalin (Tzvetkova and Kudrjaschov, 1985, cited from Okado, 1993) and Hokkaido, Japan (Okado, 1993). The East Sea, South Korea is the southern limit of distribution of A. (Atylus) ekmani. 


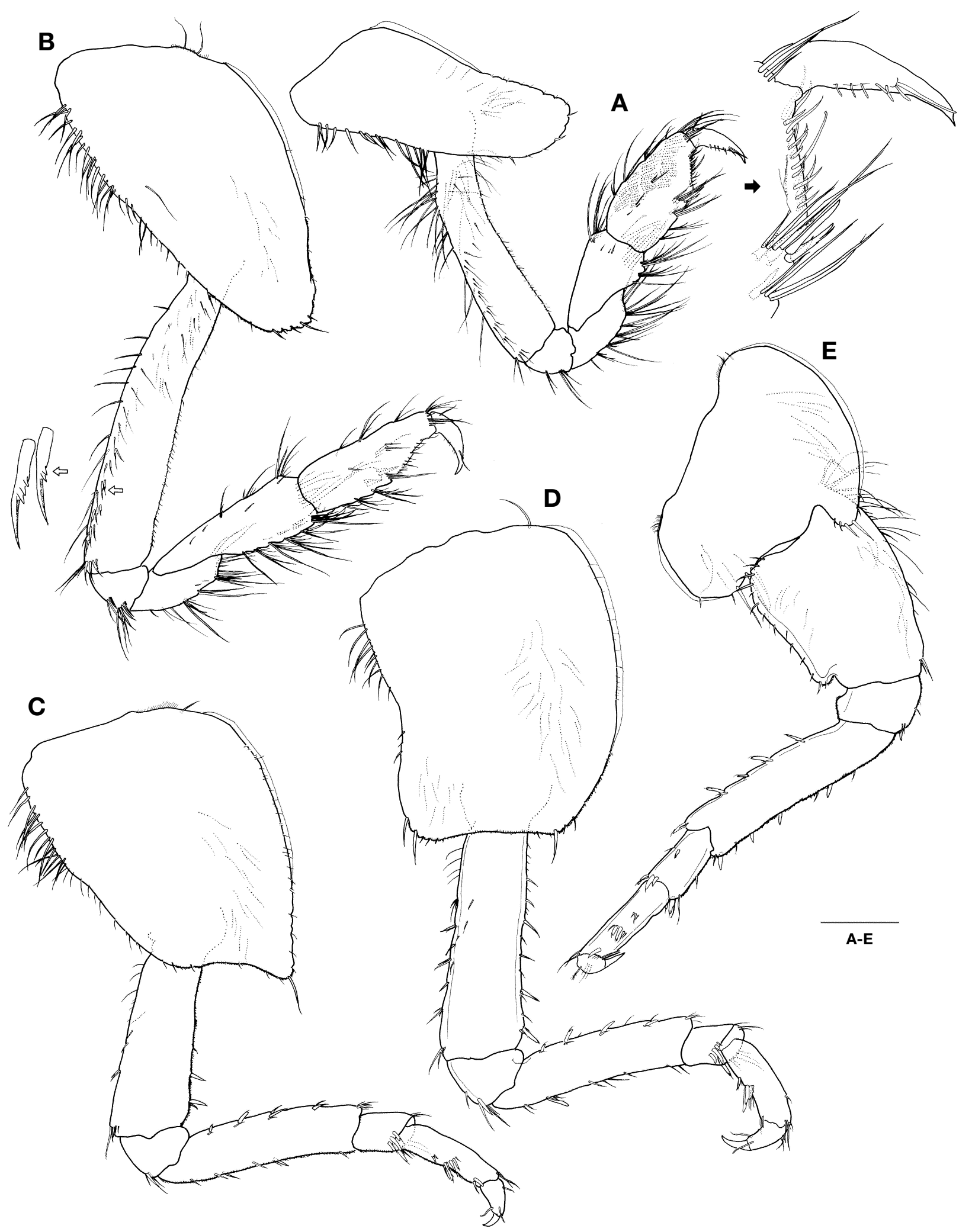

Fig. 2. Atylus (Atylus) ekmani (Gurjanova), female, $18.7 \mathrm{~mm}$ : A, gnathopod 1; B, gnathopod 2; C, pereopod 3; D, pereopod 4; E, pereopod 5 . Scale bars $=0.4 \mathrm{~mm}(A-E)$. 


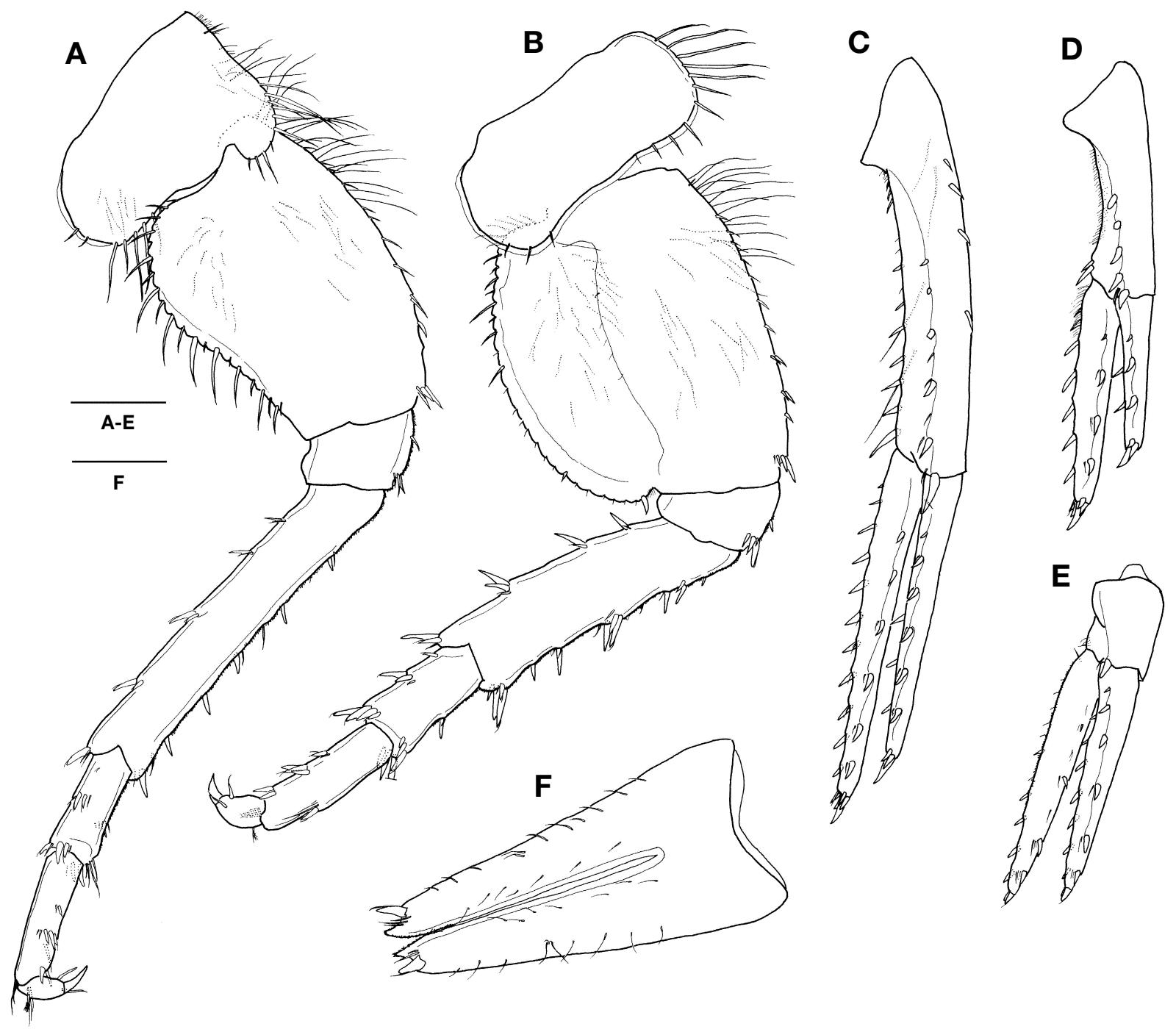

Fig. 3. Atylus (Atylus) ekmani (Gurjanova), female, $18.7 \mathrm{~mm}$ : A, pereopod 6; B, pereopod 7; C, uropod 1; D, uropod 2; E, uropod 3; $F$, telson. Scale bars $=0.4 \mathrm{~mm}(A-E), 0.2 \mathrm{~mm}(F)$.

Distribution. Korea (east coast), Japan and Russia.

\section{1*Atylus (Atylus) matsukawaensis Hirayama and Takeuchi, 1993 (Figs. 4-6)}

Atylus matsukawaensis Hirayama and Takeuchi, 1993, p. 142, Figs. 1-4.

Material examined. 5 ㅇ $^{7} 2$ 우 우, Gajin, Goseong-gun, $\left(38^{\circ}\right.$ $\left.22^{\prime} 02^{\prime \prime} \mathrm{N}, 128^{\circ} 30^{\prime} 45^{\prime \prime} \mathrm{E}\right), 20$ Oct. 2005 (Y.H. Kim); 98 speci-

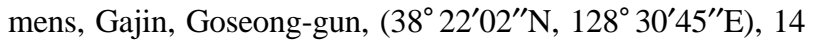
Mar. 2006 (Y.H. Kim); 258 specimens, Gajin, Goseong-gun, $\left(38^{\circ} 22^{\prime} 02^{\prime \prime} \mathrm{N}, 128^{\circ} 30^{\prime} 45^{\prime \prime} \mathrm{E}\right), 23$ Feb. 2007 (Y.H. Kim); 1 specimen, Gisamun, Yangyang-gun, $\left(38^{\circ} 00^{\prime} 38^{\prime \prime} \mathrm{N}, 128^{\circ} 43^{\prime}\right.$
46"E), 19 Dec. 2007 (Y.H. Kim); 25 specimens, Sacheon, Kangreung-si, $\left(37^{\circ} 50^{\prime} 02^{\prime \prime} \mathrm{N}, 128^{\circ} 52^{\prime} 49^{\prime \prime} \mathrm{E}\right), 8$ May 2008 (Y.H. Kim); 2 specimens, Anmok, Kangreung-si, (37 $46^{\prime}$ $\left.05^{\prime \prime} \mathrm{N}, 128^{\circ} 57^{\prime} 15^{\prime \prime} \mathrm{E}\right), 9$ May 2008(Y.H. Kim); 20 specimens, Buheung-ri, Yeongdeok-gun, $\left(36^{\circ} 17^{\prime} 34^{\prime \prime} \mathrm{N}, 129^{\circ} 22^{\prime} 42^{\prime \prime} \mathrm{E}\right)$, 20 Jun, 2008 (Y.H. Kim); 10 specimens, Namhangin, Kangreung-si, $\left(37^{\circ} 45^{\prime} 51^{\prime \prime} \mathrm{N}, 128^{\circ} 57^{\prime} 24^{\prime \prime} \mathrm{E}\right), 10 \mathrm{Jul} .2008$ (S.S. Hong); 6 specimens, Sageunjin, Kangreung-si, $\left(37^{\circ} 48^{\prime} 33^{\prime \prime} \mathrm{N}\right.$, $\left.128^{\circ} 54^{\prime} 04^{\prime \prime} \mathrm{E}\right), 11$ Jul. 2008 (S.S. Hong).

Description. Male. Body (Fig. 4A) about $6.1 \mathrm{~mm}$ long, rather compressed; head shorter than pereonites 1-3 combined; rostrum elongated, slightly curved downward, protruded between pair of antenna 1; anterior cephalic lobe slightly

$1 *$ 마츠카와납작붙은꼬리옆새우(신칭) 
pointed; eye medium, subrectangular; pereon and pleon not carinate, pleonal epimera 1-3 spinose ventrally, posterodistal corner with 1 spine.

Urosomites (Fig. 4B). Urosomite 1 carinate posterodorsally, with dorsomedian notch; urosomites 2, 3 fused, weakly carinate posterodorsally.

Antenna 1 (Fig. 4C). Slightly longer than head and pereonites 1-4 combined; ratio of length of peduncular articles $1-3=1.00: 0.85: 0.32$, article 1 and 2 with row of numerous setular tufts ventrally; accessory flagellum small, uniarticulate, with 3 unequal apical setae; its flagellum 17-segmented.

Antenna 2 (Fig. 4D). About 1.2 times as long as antenna 1; gland corn of article 2 well developed; length ratio articles $3-5=1.00: 2.81: 3.72$; dorsal margin of articles 3 , 4 with transverse row of setular tufts; their flagellum 11-segmented, slightly shorter than peduncle.

Lower lip (Fig. 4E). Inner lobe small, obscure, but slightly distinct; shoulder of outer lobe with flattened hyaline setae; both lobes densely pubescent.

Left mandible (Fig. 4F). Incisor with 6 blunt teeth; lacinia mobilis with 5 teeth; molar process well developed, strongly sclerotized, rugose marginally, with 1 pappose seta; row of 5 denticulate accessory spines and several setules placed between lacinia mobilis and molar process; palp triarticulate, length ratio $=1.00: 3.55: 2.47$, proximal segment short, distal segment slightly tapering distally, half of ventrodistal margin with 5 simple and 4 pinnate setae.

Right mandible (Fig. 4G). Similar to left one, except bearing 4 denticulate accessory spines; lacinia mobilis bifurcate, with 5 and 5(4) teeth, respectively.

Right maxilla 1 (Fig. 4H). Inner plate small, with 3-5 plumose setae; outer plate with $6+5$ dentate tooth-like spines apically; palp biarticulate, extending outer plate, with 4 conical teeth, 1 slender spine and 3 setae apically; palp of left maxilla 1 (Fig. 4I) with 4 long conical teeth and 3 setae apically.

Maxilla 2 (Fig. 4J). Inner plate slightly shorter and narrower than outer one, with 1 thick plumose seta subapically and 2 rows of 15 setae apically.

Maxilliped (Fig. 4K). Inner plate developed, lateral margin with 4-5 plumose setae, apical margin with 3 conical teeth, 3-4 plumose, 3 simple setae, exterior apicolateral side with 3-4 oblique pinnate setae and one subterminal tooth; outer plate slightly extending beyond end of palp article 2 , with 1 longitudinal row of simple setae and 8-9 conical teeth laterally, apical margin with 2-3 slender setiform teeth and 2-3 simple setae; palp 4-articulated, article 2 about 1.4 times as long as article 3 , both articles setaceous on inner margin, distal article falcate, with acute nail.

Gnathopod 1 (Fig. 5A). Coxa 1 subrectangular, ventral margin with 7 simple setae; basis slightly curved proximally, about 4/5 length of carpus and propodus combined, anterodistal margin with short setules, posterior margin with long setae; posterior margins of merus and carpus with stiff setae; propodus longish oval, about 1.6 times as long as carpus, distal $1 / 2$ of anterior side with $2,5,6$ pinnate setae or prickle spines in formula interiorly, ventral margin with 1, 2, 3, 4 spines and 3 cluster of triad pinnate setae exteriorly, 1, 2, 3, pinnate setae interiorly, palm oblique, about $1 / 2$ length of ventral margin, with tiny setae on opposite side marginally, delimited by 4 spines distally; dactylus falcate, about 0.5 times as long as propodus.

Gnathopod 2 (Fig. 5B). Similar to gnathopod 1, except for coxa 2 slightly wider than coxa 1; each articles more elongate than those of gnathopod 1.

Pereopod 3 (Fig. 5C). Coxa 3 similar to coxa 2, with 7 setae ventrally; ratio of length of articles $2-7=1.00: 0.19$ : $0.92: 0.38: 0.69: 0.29$, uniform in width.

Pereopod 4 (Fig. 5D). Similar to pereopod 3, but posterodistal margin of coxa 4 extended backward.

Pereopod 5 (Fig. 5E). Coxa 5 bilobate, anterior lobe narrow ventrally, with 1 seta, posterior lobe with 3 setae ventrodistally; basis somewhat distally narrowing, anterior margin with 1 spine and row of simple setae, 2 unequal spines on anteriodistal corner; merus to propodus spinose; ratio of length of articles $2-7=1.00: 0.22: 0.91: 0.41: 0.54: 0.22$.

Pereopod 6 (Fig. 5F). Similar to pereopod 5, but coxa 6 smaller than coxa 5 , anterior margin rather straight, following articles more longer than those of pereopod 5.

Pereopod 7 (Fig. 6A). Coxa 7 slightly concave ventromedially, basis about 0.8 times as wide as long, with broad posterior lobe, bearing 5 spines posteriorly, rounded posterodistal margin reach somewhat end of ischium; merus to propodus spinose; ratio of length of articles $2-7=1.00: 0.18$ : $0.71: 0.47: 0.56: 0.22$.

Uropod 1 (Fig. 6B). Peduncle longer than rami, about 1.3 times as long as inner ramus, with 5 lateral, 1 apicolateral, 4 medial, 2 unequal apicomedial and 3 basofacial spines respectively; both rami subequal in length, with 2 rows of spines, respectively.

Uropod 2 (Fig. 6C). Peduncle about 1.1 times as long as inner ramus, with 6 lateral, 1 apicolateral, 2 medial and 2 unequal apicomedial spines; inner ramus about 1.4 times as long as outer one.

Uropod 3 (Fig. 6D). Peduncle short, about 0.4 times as long as inner ramus, with 2 apicolateral spines; inner ramus about 1.2 times as long as outer one.

Telson (Fig. 6E). Broader than long, about 1.2 times as wide as long, cleft to $70 \%$ of its length, dorsal surface of each lobe with pair of penicillate setae medially, 2 setules marginally and apex with 1 spine and 1 penicillate seta, respectively. 
Four Species of Atylus from Korea

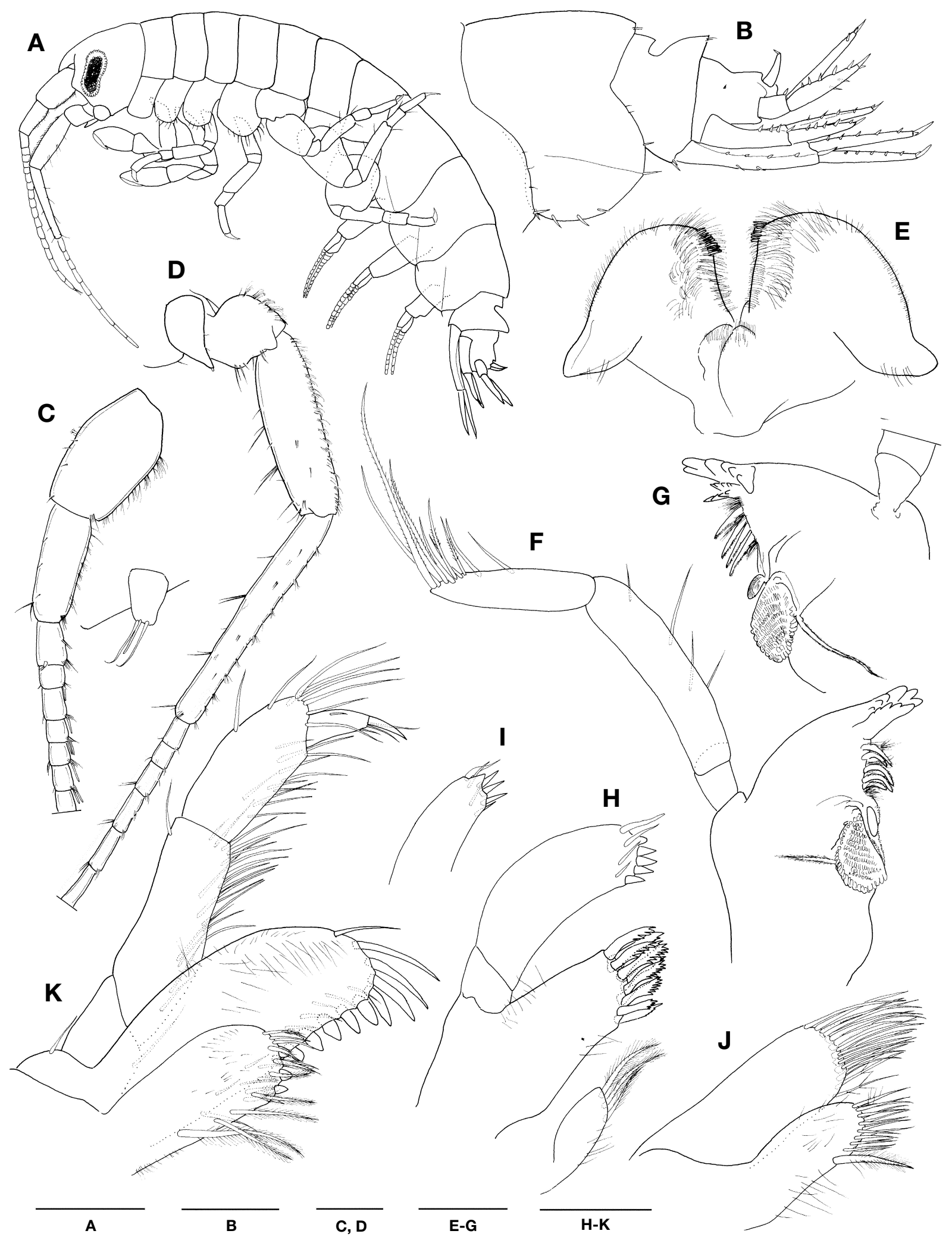

Fig. 4. Atylus (Atylus) matsukawaensis Hirayama and Takeuchi, male, $6.1 \mathrm{~mm}$ : $\mathrm{A}$, habitus, lateral; $\mathrm{B}$, pleonite 3 and urosomites; $\mathrm{C}$, antenna $1 ; \mathrm{D}$, antenna 2; $\mathrm{E}$, lower lip; $\mathrm{F}$, left mandible; $\mathrm{G}$, right mandible; $\mathrm{H}$, left maxilla $1 ; \mathrm{I}$, palp of right maxilla $1 ; \mathrm{J}$, maxilla $2 ; \mathrm{K}$, maxilliped. Scale bars $=1.0 \mathrm{~mm}(A), 0.4 \mathrm{~mm}(B), 0.2 \mathrm{~mm}(C, D), 0.1 \mathrm{~mm}(E-K)$. 


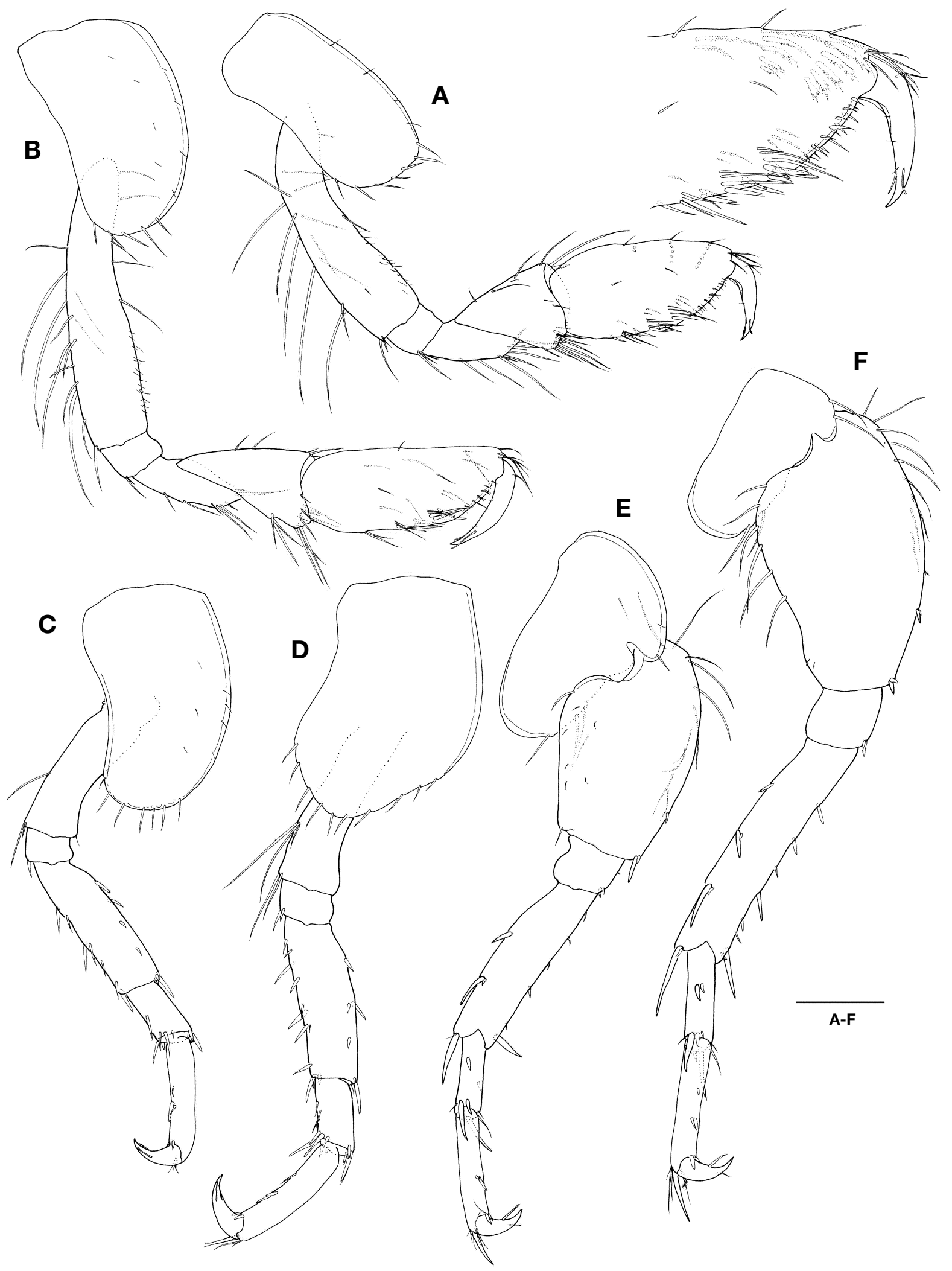

Fig. 5. Atylus (Atylus) matsukawaensis Hirayama and Takeuchi, male, $6.1 \mathrm{~mm}$ : A, gnathopod 1; B, gnathopod 2; C, pereopod 3; D, pereopod 4; E, pereopod 5; F, pereopod 6 . Scale bars $=0.2 \mathrm{~mm}(A-F)$. 


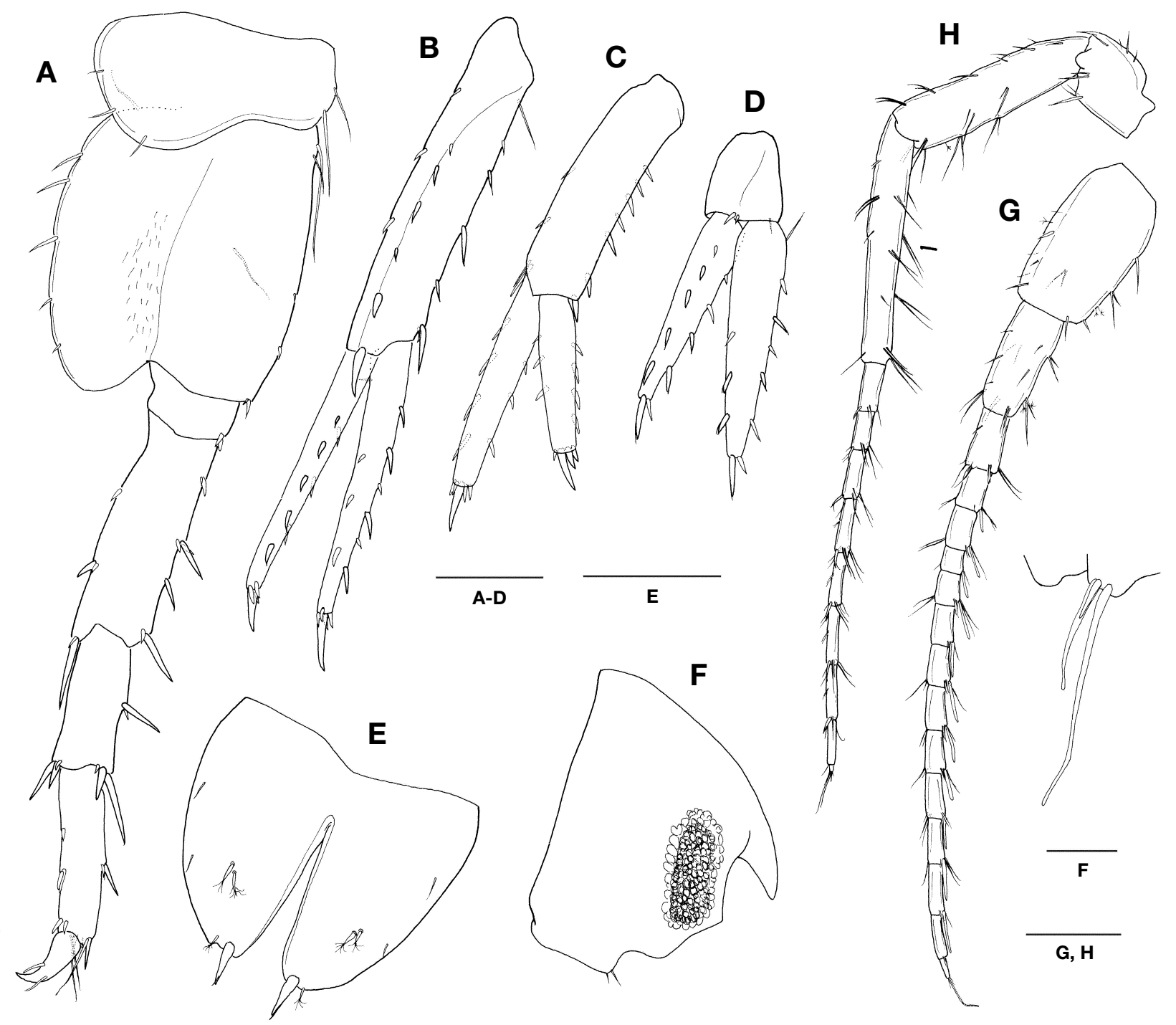

Fig. 6. Atylus (Atylus) matsukawaensis Hirayama and Takeuchi, male, $6.1 \mathrm{~mm}$ : A, pereopod 7; B, uropod 1; C, uropod 2; D, uropod 3; E, telson; Atylus n. sp., female, $5.8 \mathrm{~mm}$ : F, head; G, antenna $1 ; \mathrm{H}$, antenna 2. Scale bars=0.2 mm (A-D, F-H), $0.1 \mathrm{~mm}(\mathrm{E})$.

Ovigerous female. Body length about $5.8 \mathrm{~mm}$, oostegites enveloped in 6 eggs, similar to male in shape, but eye (Fig. $6 \mathrm{~F})$ smaller than that of male, posterior margins of peduncular articles 1, 2 of antenna 1 (Fig. 6G) and articles 3-5 of antenna 2 (Fig. $6 \mathrm{H}$ ) without transverse rows of setular tufts. Remarks. Atylus (Atylus) matsukawaensis Hirayama and Takeuchi, 1993 is characterized by having roundish pereon and pleon dorsally, prominently short carpus of pereopod 5 and 3-dentate incisor in both mandibles. Our specimens are comparatively congruent with the original description. However, several morphological differences are found between our specimens and original description: 1) the incisor on mandible bearing 6 blunt teeth in our specimens, while 3 teeth in original description, which is an important characteristic in Atylus (Atylus) matsukawaensis. Among teeth, our specimens bear 3 conspicuous and 3 minute teeth, respectively. It is possible that Hirayama and Takeuchi overlooked those minute teeth; 2) the accessory flagellum on antenna 1 bearing 3 unequal setae apically, while 2 setae in original description; 3) the inner plate of maxilliped bears 3 apical conical teeth and one outer subterminal tooth, while 4 conical teeth in original description; and 4) the telson is broader than long, while almost as long as wide in original description.

Distribution. Korea (east coast) and Japan. 

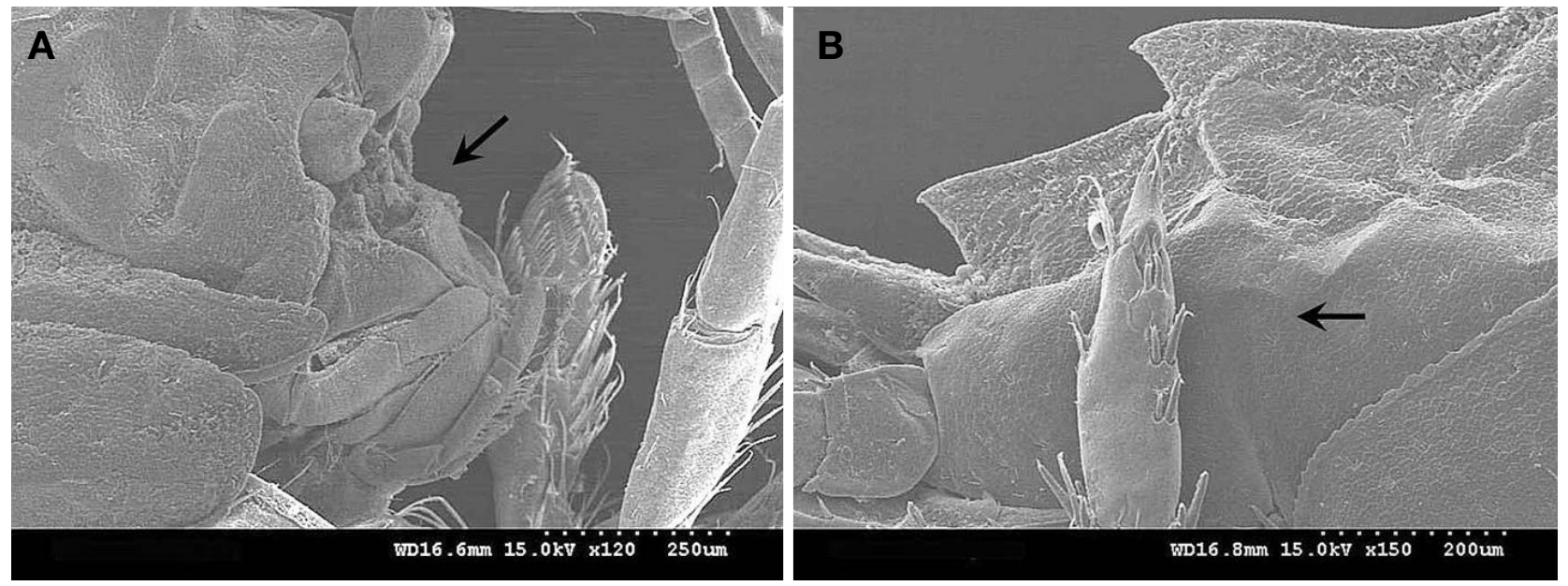

Fig. 7. Atylus (Kamehatylus) japonicus, Nagata, female, $7.5 \mathrm{~mm}$ : A, head, lateral; B, urosomites.

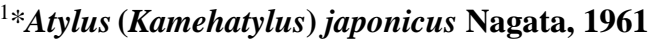 \\ (Figs. 7-10)}

Atylus japonicus Nagata, 1961, p. 216, figs. 1, 2; 1965, p. 178, fig. 19; Ledoyer, 1979, p. 156, fig. 7II; 1984, p. 42, fig. 20 .

Material examined. 1 우, Jukcheon, Pohang-si, $\left(36^{\circ} 05^{\prime} 20^{\prime \prime} \mathrm{N}\right.$, $\left.129^{\circ} 25^{\prime} 11^{\prime \prime} \mathrm{E}\right), 28$ Nov. 2001 (Y. Eun); 6 우 우, Geojin, Goseong-gun, $\left(38^{\circ} 26^{\prime} 38^{\prime \prime} \mathrm{N}, 128^{\circ} 27^{\prime} 57^{\prime \prime} \mathrm{E}\right), 11$ Apr. 2002 (Y.H. $\mathrm{Kim}) ; 7$ 우 우, Puraengi, Chujado Is., $\left(33^{\circ} 54^{\prime} 36^{\prime \prime} \mathrm{N}, 126^{\circ} 19^{\prime}\right.$ 29"E), 14 Nov. 2008 (Y.H. Kim).

Description. Ovigerous female: Body (Fig. 8A) about 8.2 $\mathrm{mm}$ long and compressed laterally. Pereonite 6 to pleonite 3 dorsally carinate, with posterodorsal tooth, respectively. Urosomites 1-3 (Fig. 7B) coalesced, with 2 dorsal teeth. Oostegites enveloped in 8 eggs. Rostrum (Fig. 8B) elongated, but not extending beyond article 1 of antenna 1. Eye round, small. Pleonal epimera 1-3 (Fig. 8C) with 7, 3, 4 anteroventral setae and 1 posteroventral seta, respectively.

Antenna 1 (Fig. 8D). Ratio of length of peduncular articles $1-3=1.00: 0.71: 0.41$; article 1 stout, 0.44 as wide as long, article 21.75 times as long as article 3; flagellum 10-segmented including short distal segment, single aesthetasc is located at each segment on flagellum.

Antenna 2 (Fig. 8E). Peduncle more than twice length of flagellum; peduncular articles 1-3 short, peduncular article 51.32 times as long as article 4, 1.08 times as long as flagellum; flagellum 6-segmented, with 1 spine and several setae at segments.

Lower lip (Fig. 8F). Inner lobe indistinct; outer lobe well developed, with row of flattened hyaline spines subapically, covered with dense pubescence.
Left mandible (Fig. 8G). Incisor and lacinia mobilis produced forward, blunt, roundish, with 4 and 5 teeth, respectively; molar process strong and massive, truncate, with a pappose setae; row of several stout and plumose slender setae placed between lacinia mobilis and molar process; palp absent.

Right mandible (Figs. 7A, 8H). Similar to left mandible, but Incisor with 5 blunt teeth, lacinia mobilis bifurcate, distal branch with 5, proximal branch with 4 blunt teeth, respectively; molar bearing long pappose seta.

Left maxilla 1 (Fig. 8I). Inner plate bearing 4 pinnate setae apically; outer plate with 10 sclerotized bifid, trifid or serrate stout spines; palp biarticulate, proximal article short, 0.38 times as long as distal article, distal article with 6 simple setae apically, and 6-7 conical spines, but palp on right maxilla (Fig. 8J) bearing 5 conical spines and 1 seta, respectively.

Maxilla 2 (Fig. 8K). Inner plate smaller than outer plate, armed with large pinnate seta subterminally; apical and subapical margins of both plates with closely simple or pinnate setae.

Maxilliped (Fig. 8L). Inner plate slightly extending more than one-half length of outer plate, with row of pinnate setae laterally, 3 conical teeth apically; outer plate reaching distal margin of article 2 of palp; palp 4-articulate, article 2 longer than the other articles, 1.52 times as long as article 3.

Gnathopod 1 (Fig. 9A). Coxa 1 tapering distally, bearing marginal setules; basis bearing row of short setules anteriorly, long setae posteroproximally, row of short setae distal $2 / 3$ of posterior margin, 1.39 times as long as merus and carpus combined; propodus (Fig. 9B) elongate-ovate, 0.85 times as long as carpus, palm oblique, with feeble setae marginally,

\footnotetext{
$1 *$ 일본납작붙은꼬리옆새우(신칭)
} 


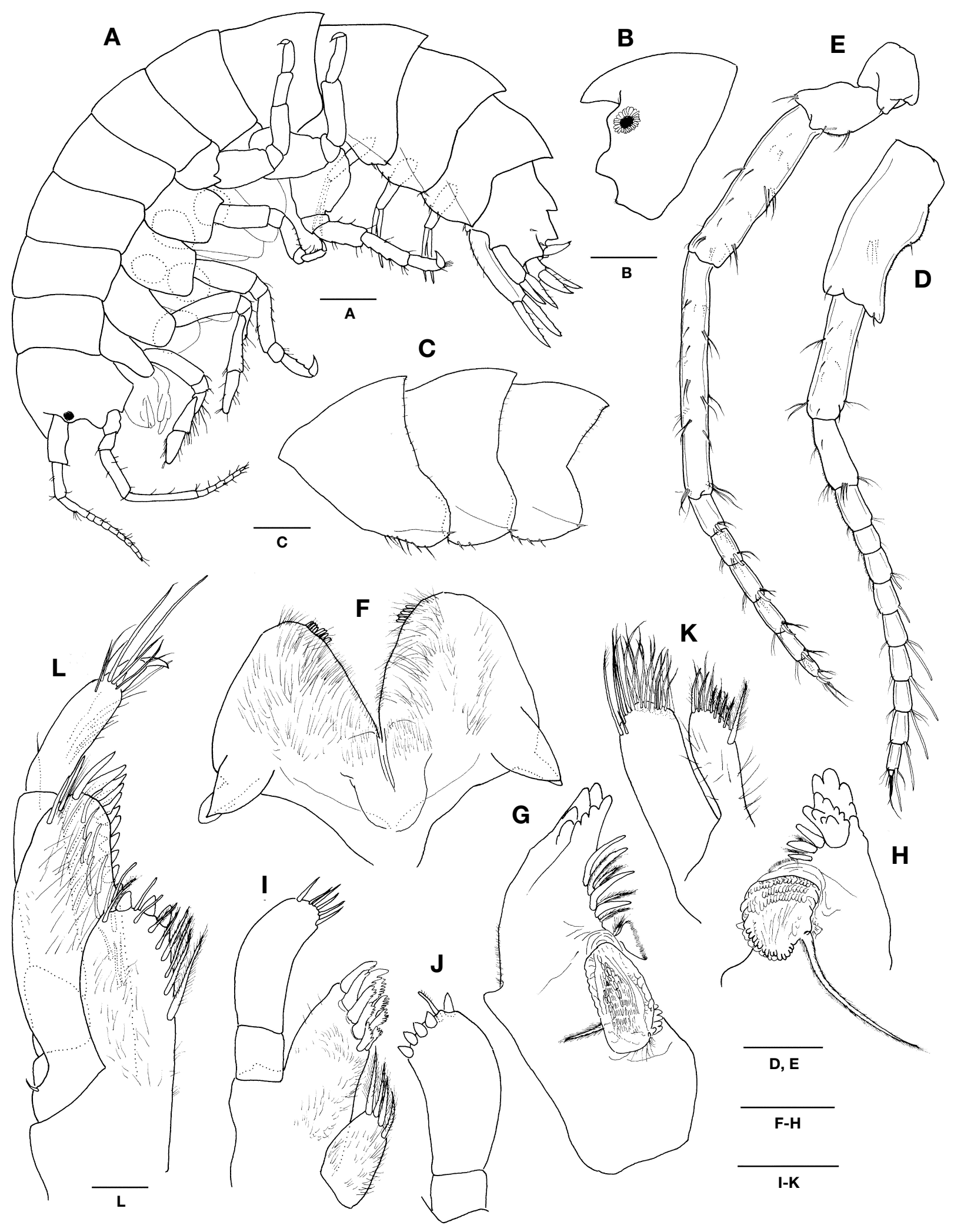

Fig. 8. Atylus (Kamehatylus) japonicus Nagata, female, $8.2 \mathrm{~mm}$ : $\mathrm{A}$, habitus, lateral; $\mathrm{B}$, head; C, pleonites; $\mathrm{D}$, antenna $1 ; \mathrm{E}$, antenna 2; $\mathrm{F}$, lower lip; $\mathrm{G}$, left mandible; $\mathrm{H}$, right mandible; $\mathrm{I}$, left maxilla $1 ; \mathrm{J}$, palp of right maxilla $1 ; \mathrm{K}$, maxilla 2 ; $\mathrm{L}$, maxilliped. Scale bars $=0.5 \mathrm{~mm}(A), 0.4 \mathrm{~mm}(B, C), 0.2 \mathrm{~mm}(D, E), 0.1 \mathrm{~mm}(F-K), 0.05 \mathrm{~mm}(L)$. 
Young-Hyo Kim and Kyung-Sook Lee

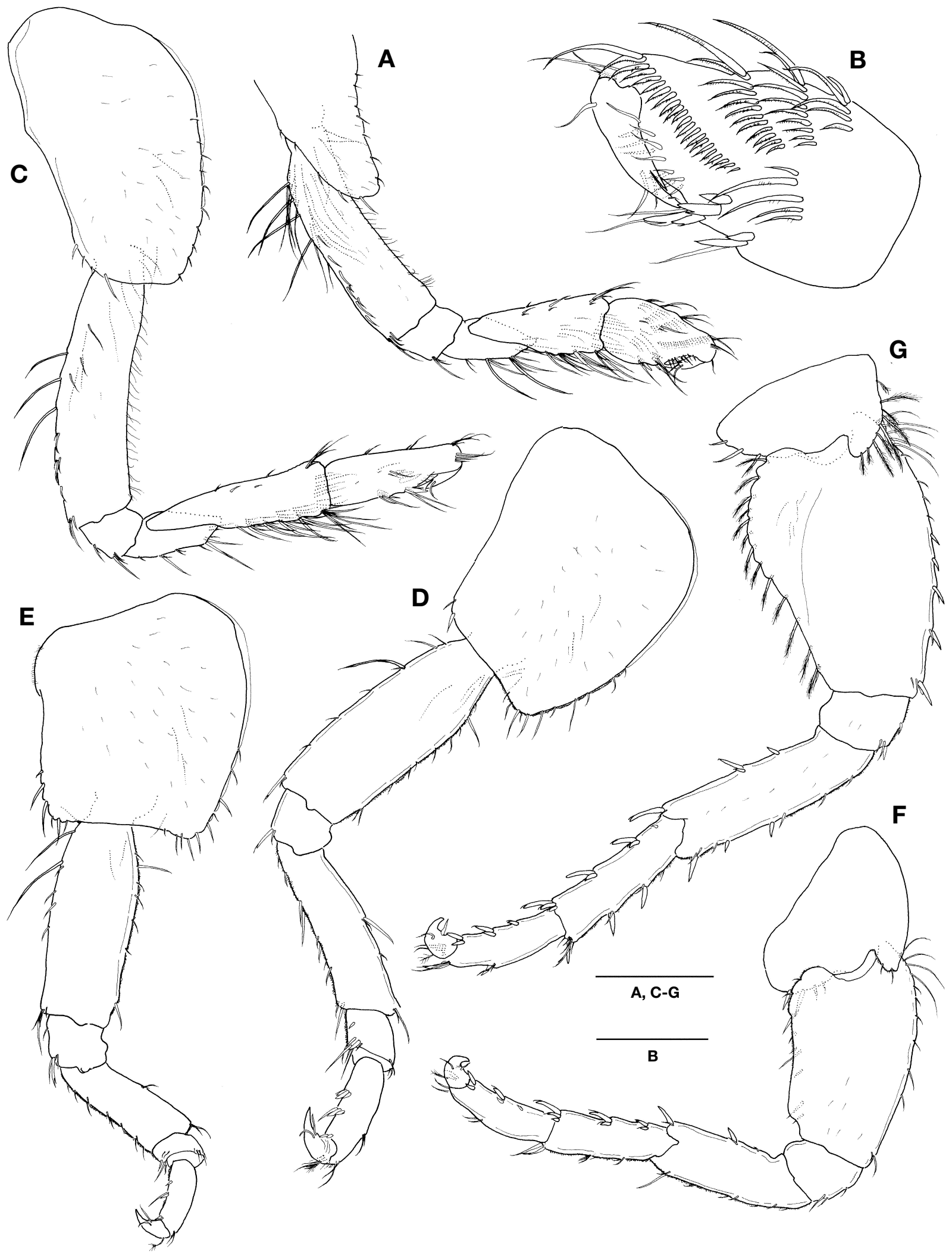

Fig. 9. Atylus (Kamehatylus) japonicus Nagata, female, $8.2 \mathrm{~mm}$ : A, gnathopod 1 ; $\mathrm{B}$, inner view of propodus of gnathopod 1 ; $\mathrm{C}$, gnathopod 2; D, pereopod 3; E, pereopod 4; F, pereopod 5; G, pereopod 6. Scale bars=0.3 mm (A, C-G), $0.1 \mathrm{~mm}(B)$. 

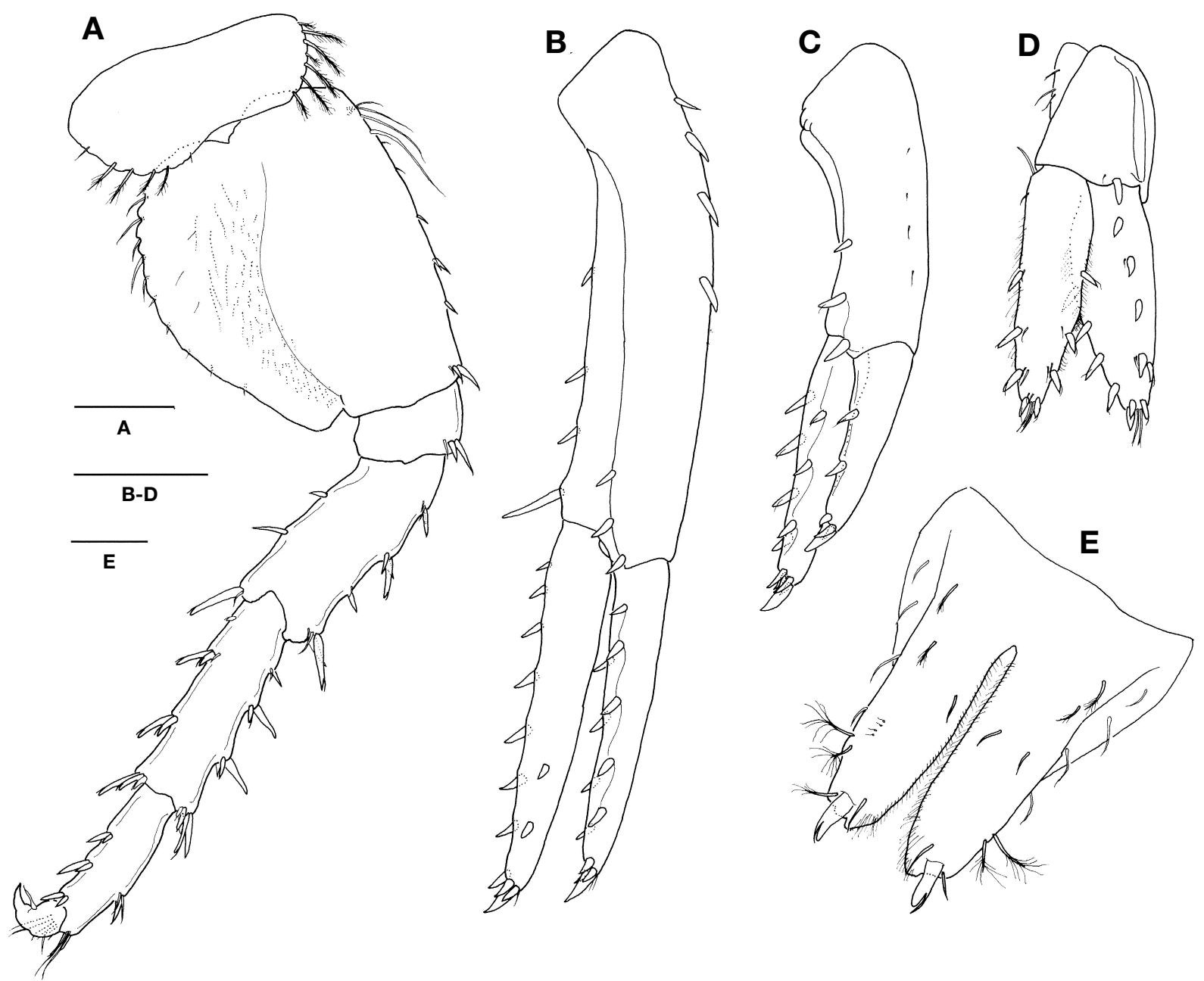

Fig. 10. Atylus (Kamehatylus) japonicus Nagata, female, $8.2 \mathrm{~mm}$ : A, pereopod 7; B, uropod 1; C, uropod 2; D, uropod 3; E, telson. Scale bars $=0.2 \mathrm{~mm}(A-D), 0.05 \mathrm{~mm}(E)$.

palmar corner bearing two group of spines and setae, inner face bearing four oblique rows of simple or unipinnate setae and 5 mesial setae; dactylus falcate, fit in the palm, about $1 / 2$ length of propodus.

Gnathopod 2 (Fig. 9C). Similar to gnathopod 1, but somewhat longer, especially carpus and propodus; ventral margin of coxa 2 nearly straight; carpus slender, 1.28 times as long as propodus, with five clusters of stiff setae posteriorly.

Pereopod 3 (Fig. 9D). Coxa 3 quadrate, with feeble setae on anterodistal corner; basis 1.29 times as long as merus; propodus 1.84 times as long as dactylus, bearing three clusters of spines on posterior margin.

Pereopod 4 (Fig. 9E). Similar to pereopod 3, but each article shorter than that of pereopod 3.

Pereopod 5 (Fig. 9F). Coxa 5 anteriorly curved, bilobate, anterior lobe protruding downward, with 2 setae; basis subrectangular, dorsomedial portion concavely sunken, 1.34 times as long as merus; carpus 1.19 times as long as propodus, with three clusters of spines on posterior margin.

Pereopod 6(Fig. 9G). Similar to pereopod 5, but larger and more spiniferous; anterior margin of coxa 6 with 9 pinnate setae; basis with 5 long setae anteroproximally, anterior margin with row of spines, posterior margin with row of 13 pinnate setae; merus 0.78 times as long as basis, 1.37 times as long as carpus.

Pereopod 7 (Fig. 10A). Coxa 7 subrectangular, wider than long, with 7 long to short pinnate setae anteriorly, 1 short and 4 pinnate setae on posteroventral corner; basis convexly rounded, 0.81 times as wide as long; merus subequal in length to carpus, 0.72 times as long as propodus; merus to propodus bearing longitudinal row of spines along both margins.

Uropod 1 (Fig. 10B). Peduncle 1.46 times as long as inner ramus, bearing 3 dorsolateral spines distally, 4 medial and basofacial spines, respectively; outer ramus 0.87 times as 
long as inner one, with two longitudinal rows of spines.

Uropod 2 (Fig. 10C). Peduncle 1.23 times as long as inner ramus, bearing 3 dorsolateral spines; inner ramus 1.25 times as long as outer one.

Uropod 3 (Fig. 10D). Peduncle comparatively short, with 1 spine distally; both rami subequal in length, 1.74 times as long as peduncle.

Telson (Fig. 10E). Comparatively longish, cleft about 3/4 of its length, each lobe bears 2 supple penicillate setae lateroproximally, 1 or 2 feeble setae medially, 2 penicillate setae laterodistally, apices with stout robust spine, feeble and penicillate setae, respectively.

Remarks. In the family Dexaminidae, the loss of madibular palp is major distinction between atylids and dexaminids (Barnard 1970). But among the atylids which have generally mandibular palp, the subgenus Kamehatylus is characterized by the absence of mandibular palp and the coalescence of 13 urosomites. As yet, only two species of Kamehatylus are recorded around the world: A. (Kamehatylus) nani Barnard, 1970 from the Hawaiian Islands, and A. (Kamehatylus) processicer Sivaprakasam, 1970 from the India. The Japanese atylid, Atylus japonicus Nagata, 1961, is similar to the species of the subgenus Kamehatylus. Nagata described that mandibular palp might be broken, but that was probably absent as noted by Barnard (1970). Our specimens from Korea are congruent with Nagata (1961)'s original description and possess the features of Kamehatylus, such as the absence of mandibular palp and the coalescence of 1-3 urosomites. Therefore, A. japonicus Nagata, 1961 might be belonging to the subgenus Kamehatylus. Minor morphological differences are found between our specimens and Japanese ones of Nagata (1961)': 1) the inner lobe of maxilla 1 with 4 plumose setae, while 3 setae in the Japanese specimens; 2) the outer lobe of maxilla 1 with 10 serrate spines, while 8 serrate spines in the Japanese specimens; 3 ) the merus of pereopods 6-7 slightly longer than carpus, while they are subequal in length in the Japanese specimens; 4) the merus and carpus of pereopod 7 subequal in length, while carpus longer than merus in the Japanese specimens.

Distribution. Korea, Japan, Moluccas and New Caledonia.

\section{ACKNOWLEDGEMENTS}

This research was supported by a grant (no. 2006-421) and (no. 2007-491-1) from the Ministry of Environment of the Korean Government.

\section{REFERENCES}

Barnard, J.L., 1958. Index to the families, genera, and species of the gammaridean Amphipoda (Crustacea). Allan Hancock Found. Publ., Occ. Pap., 19: 1-145.

Barnard, J.L., 1970. Sublittoral Gammaridea (Amphipoda) of the Hawaiian Islands. Smith. Contrib. Zool., 34: 1-286.

Barnard, J.L. and G.S. Karaman, 1991. The families and genera of marine gammaridean Amphipoda (except marine gammaroids). Rec. Austr. Mus., Suppl., 13: 1-866.

Bulycheva, A.I., 1957. Morskie bloxi morey SSSR i sopredel'nyx vod (Amphipoda, Talitroidea). Opred. Faune SSSR, Akad. Nauk SSSR, 65: 1-185, figs. 1-66.

Gurjanova, E., 1938. Amphipoda Gammaroidea of Siaukhu Bay and Sudzukhe Bay (Japan Sea). Rep. Japan Sea Hydrobiol. Exp. Zool. Inst. Acad. Sci. USSR in 1934, 1: 241-404.

Gurjanova, E., 1951. Amphipoda of adjacent sea of SSSR. (Amphipoda-Gammaridea). Opred. Faune SSSR, Akad. Nauk SSSR, 41: 1-1029.

Hirayama, A. and I. Takeuchi, 1993. New species and New Japanese records of the Gammaridea (Crustacea: Amphipoda) from Matsukawa-ura Inlet, Fukushima Prefecture, Japan. Publ. Seto Mar. Biol. Lab., 36(3): 141-178.

Kim, C.B., H.S. Kim and W. Kim, 1992. Three new species of gammaridean amphipod (Crustacea) from Korean waters. Korean J. Syst. Zool. Special Iss., 3: 101-112.

Kim, Y.H., Y. Eun and K.S. Lee, 2006. Two new records of Dexaminidae (Crustacea: Amphipoda) from Korea. Korean J. Syst. Zool., 22(1): 37-49.

Kim, Y.H. and K.S. Lee, 2008. A new species of the genus Paradexamine (Crustacea: Amphipoda: Dexaminidae) from Korea. Ani. Cell. Sys., 12(3): 157-163.

Ledoyer, M., 1979. Expédition Rumphius II (1975). Crustacés parasites, commensaux etc... (Th. Moned et R. Serène, éd). VI: Crustacés Amphipodes gammariens. Bull. Mus. Natn. Hist. Nat. Paris, 4e sér., 1: 137-181, figs. 1-19.

Ledoyer, M., 1984. Les gammariens (Crustacea, Amphipoda) des herbiers des phanerohames marines de Nouvelle Caledonie (region des Noumea). Mem. Mus. Natn. Hist. Nat. Ser. A, zool., 129: 1-113.

Nagata, K., 1961. A new Atylid Amphipod from Japan. Annot. Zool. Japan., 34(4); 216-218.

Nagata, K., 1965. Studies on marine gammaridean Amphipoda of the Seto Inland Sea. II. Publ. Seto Mar. Biol. Lab., 13: 171-186.

Okado, M., 1993. The occurrence of Atylus ekmani (Gajanova, 1938) (Crustacea, Amphipoda, Gammaridea) from Southern Hokkaido, Japan. Bull. Fac. Fish. Hokkaido Univ., 44(1): 6-14.

Ren, X., 2006. Fauna Sinica, Invertebrata, Vol 41. Crustacea, Amphipoda, Gammaridea. Science Press Beijing, 1-588.

Tzvetkova, N.L., 1968. On the fauna and ecology of Amphipods (Amphipoda, Gammaridea) of the Possjet Bay (the Sea of Japan). Acad. Sci. USSR, Zool. Inst. Expl. Fauna Seas, 5: 160-195. 